\title{
25 PUBLIC PROCUREMENT OF IS/IT SERVICES: Past Research and Future Challenges
}

\author{
Josep M. Marco-Simó \\ Joan A. Pastor \\ Rafael Macau \\ Universitat Oberta de Catalunya \\ Barcelona, Spain
}

\begin{abstract}
In this paper we present the current state-of-the-art situation of research in public administration procurement of functions and services related to information systems and information technologies. From this review, we propose a list of open research issues according to our beliefs and practical experience. Finally we introduce a real case that we are starting to address, in which we want to consider both prior results as well as research issues. We believe that the topic of IS/IT procurement in public administration is an open area that has not received enough attention from the research community, according to the great amount of public money that is being invested.
\end{abstract}

Keywords Public procurement methods, IS and IT services, outsourcing in public administration

\section{INTRODUCTION AND THE IMPORTANCE OF PUBLIC IS/IT PROCUREMENT}

In this paper we present the current state-of-the-art of research in public administration procurement of functions and services related to information systems and information technologies. From this review we present a tentative list of open research issues

Please use the following format when citing this chapter:

Marco-Simó, M., Pastor, Joan A., and Macau, R., 2008, in IFIP International Federation for Information Processing, Volume 287, Open IT-Based Innovation: Moving Towards Cooperative IT Transfer and Knowledge Diffusion, eds. León, G., Bernardos, A., Casar, J., Kautz, K., and DeGross, J. (Boston: Springer), pp. 443-460. 
and we introduce the real-life case that we are starting to address, to which we want to apply both prior results as well as open issues.

In a common trend shared with private enterprises, during the 1980 s public administration organizations (PAOs) started experimenting with outsourcing as a way to acquire their IS and IT goods and services (Beyah and Gallivan 2001; Hancox and Hackney 1999). The basic purpose of outsourcing is to externalize those organizational activities that are not directly related to the core competences of the organization. The core competences of a PAO are those related to giving the citizen final services, not necessarily by doing these services, but managing their acquisition and control. Thus, the PAO needs IS and IT to develop internal functions as well as to provide citizens with external services, which could be considered a target to be outsourced (i.e., to be procured or acquired from external service companies). In general, the inherent risks and opportunities of outsourcing have been studied and rules for managing it are clearly drawn up (Lee et al. 2003), so IS/IT outsourcing is seen as a reliable option for the general case.

Currently, PAOs are investing great amounts of public money on IS and IT. According to a report by the Gartner Group (Sood 2007), the U.S. federal government spent $\$ 66$ billion on IS/IT goods and services in 2006 and 11 percent of professional personal computers worldwide were purchased by government agencies. The report also mentions that the procurement of such systems and services is mainly done through market suppliers.

Given these data and from an economic point of view, at least two arguments appear in order to defend the importance of paying attention to this topic:

- Efficiency of the management of public money. Monitoring its correct use is one of the social requirements that governments must accomplish in order to address the usual citizens' concerns about PAOs.

- Leadership of PAOs as a great IS consumer. PAOs can become leaders in promoting positive changes in the way that IS outsourcing is performed. For example,

- By including adequate references to methodologies or standards in IS calls-fortenders (i.e., CMMI, ITIL, or COBIT), as a compulsory and valuable requirement to accepting bids from possible providers. This automatically increases the perceived importance and interest of those methodologies or standards within the IS industry.

- By developing and following some specific methodologies for the PAO acquisition process, such as Euromethod (Helmerich 1998), ISPL (Dekker 2002), or CMMI-ACQ (Hoffman 2007).

From a scientific research point of view, it is interesting to know how IS outsourcing in PAO literature has described issues such as

- Its actual application to real cases. For example by locating, depicting, analyzing, and comparing different real experiences or case studies; by adapting existing theories (from economic ones, such as agency or transaction costs, to organizational ones, such as social exchange or power politics); by describing innovation within IS outsourcing practices (from qualifying providers to monitoring relationships), 
following trends (from total to selective outsourcing, from global to local outsourcing), or studying the use of IS/IT outsourcing methodologies or relevant standards (from specific ones like ISPL to general ones such as CMMI or ITIL).

- Contextual and idiosyncratic similarities and differences between the public and the private sector influence the application of IS outsourcing. For example, trying to find if accepted trends exist that work in the private sector but that cannot be applied to the public one, or that have a different level of usefulness in this specific context.

- The existence of specific recommendation frameworks for IS outsourcing in PAOs, through adapting the accepted approaches in private sectors, or by developing new ones.

A deeper knowledge on the above issues will help us to face an updated research agenda and also can give us some clues about which items could be interesting to analyze in future case studies.

The paper is organized as follows. In section 2 we present, describe, and contextualize all prior research that we have found directly related to PAO procurement of IS/IT services. By following the same classification of issues, in section 3 we provide, according to our conceptual point of view and our practical experience, a list of open issues to be considered for further research. In section 4 we introduce an initial explanation of the context of the case that we are undertaking, a case where we are considering all of the issues addressed in prior research as well as open research issues. We end by presenting some short conclusions.

\section{PAST RESEARCH IN PUBLIC ADMINISTRATION PROCUREMENT OF IS/IT SERVICES}

\subsection{Quantitative Summarization of Past Research}

In this section, we present an up-to-date review of prior research in PAO procurement of IS/IT services. After this rather straightforward quantitative enumeration and classification of related research, in the next section we will provide a qualitative and more commented review.

A recent paper on IS outsourcing in PAOs (Marco-Simó et al. 2007) already selected and commented in detail on those prior contributions published in scientific IS journals having to do with IS outsourcing specifically in PAOs. That study used sources given by Dibbern et al. (2004) and González et al. (2006), and used as keywords both the general term outsourcing, as well as its derivatives and other related names (sourcing, insourcing, cosourcing, offshoring, nearshoring, and externalization), as well as other terms more specifically related to procurement, as one of the first phases within outsourcing projects (such as acquisition, supply, and contract). These keywords were used not only in title, abstract, and keyword searches, but also in the content of the entire paper.

While keeping the same search keywords and browsing carefully journal and conference contents, in this paper we augment the scope of our bibliographic review, both in a longitudinal and temporal way, by including papers from scientific public admin- 
istration journals, international IS congresses, and some other scientific journals usually addressing issues within PA and IS, such as those related to IFIP Working Group WG8.5 (Information Systems in Public Administration).

Additionally, by following the thread of references, we have also located other papers in sources different from those originally addressed and mentioned above, that is, sources outside of our established scope and basically within the general management field. These other sources, however, have not been reviewed to find more relevant references. In order to expand our knowledge of the context, in future extensions of this work we plan to examine other sources not usually considered as research sources. Among these sources we consider publications that address professionals and publications delivered by large government bodies and organizations, for example, OECD.

As an initial quantitative description and following our review process, Tables 1 and 2 summarize the papers we found related to PAO procurement of IS/IT services.

A first and straightforward consideration is that the number of relevant references is not great, with a total of 33 research contributions from 1993 to the present. Figure 1 represents quantitatively those papers along their publication year and classified in terms of the main field (PA, IS, or management) and nature (journal or congress) of their source.

Taking into account Tables 1 and 2, Figure 1, and the specific sources, we observe that the 33 papers are quite dispersed, both in terms of source type (at the most, three papers come from a single journal or congress in the analyzed period) and time (at the most, five references were published in a single year, in 2002). IS journals have addressed the issue with more papers than PA journals (more specifically from 1996 to 2002). In fact, PA journals have included relevant papers less intensively and more sporadically, since they concentrate more on PA social, legal, and citizen service aspects, rather than on operational and technological themes.

All in all, journal publications in our addressed topic have been very few, while IS congresses have addressed it with more references, more regularly in the past years. It is significant from Table 1 that many well-known journals from PA and IS have not published yet a single contribution in PA procurement of IS/IT services. After checking all of the publications listed on the IFIP Working Group WG 8.5 website, we have to remark that none of them includes a single paper on this topic.

\subsection{Qualitative Discussion of Past Research}

In the previous section, we accounted for a total of 33 papers, irrespective of their relative relevance in qualitative terms such as orientation, depth, rigor or novelty of the contributions. After analyzing them along these lines, we conclude that only 10 papers can be considered as highly relevant, while another set of 7 papers are of medium relevance to our topic, with the others being of lesser interest to our research, for various reasons.

In any case, as discussed here, we detect a clear dispersion of subtopics in which the papers are focused, as well as of their respective research approaches. We attempt to group and classify in the following subsections the various contributions of the 17 most relevant papers, where subsections account for the diverse relevant classification categories that we have drawn from the study. 
Table 1. References from Scientific Information Systems and Public Administration Journals

\begin{tabular}{|c|c|c|c|c|}
\hline Source & $\begin{array}{c}\text { Period } \\
\text { Reviewed }\end{array}$ & Field & Author & Year \\
\hline Communications of $A C M$ & $1992-2007$ & IS & Slaughter and Ang & 1996 \\
\hline \multirow{3}{*}{$\begin{array}{l}\text { European Journal of Information } \\
\text { Systems }\end{array}$} & \multirow[t]{3}{*}{$1996-2007$} & \multirow[t]{3}{*}{ IS } & Currie & 1996 \\
\hline & & & Willcocks and Kern & 1998 \\
\hline & & & Allen et al. & 2002 \\
\hline \multirow[t]{2}{*}{ Information Systems Journal } & \multirow[t]{2}{*}{$1996-2007$} & \multirow[t]{2}{*}{ IS } & Lacity and Willcocks & 1997 \\
\hline & & & Hancox and Hackney & 2000 \\
\hline \multirow{3}{*}{$\begin{array}{l}\text { Journal of Information } \\
\text { Technology }\end{array}$} & \multirow[t]{3}{*}{$1988-2007$} & \multirow[t]{3}{*}{ IS } & De Looff & 1995 \\
\hline & & & Lewis & 1999 \\
\hline & & & Domberger et al. & 2000 \\
\hline $\begin{array}{l}\text { International Journal of } \\
\text { Information Management }\end{array}$ & $1998-2005$ & IS & No references found & \\
\hline $\begin{array}{l}\text { Industrial Management and Data } \\
\text { Systems }\end{array}$ & $1998-2005$ & IS & No references found & \\
\hline Information and Management & $1998-2005$ & IS & No references found & \\
\hline Information and Organization & $1998-2005$ & IS & No references found & \\
\hline Information Systems Research & $1998-2005$ & IS & No references found & \\
\hline $\begin{array}{l}\text { Journal of Management } \\
\text { Information Systems }\end{array}$ & $1998-2005$ & IS & No references found & \\
\hline MIS Quarterly & $1998-2005$ & IS & No references found & \\
\hline Public Administration Review & $2000-2007$ & PA & Globerman and Vining & 1996 \\
\hline $\begin{array}{l}\text { International Journal of Public } \\
\text { Administration }\end{array}$ & $1988-2007$ & $\mathrm{PA}$ & Danzinger and Andersen & 2002 \\
\hline Public Administration & $1988-2007$ & $\mathrm{PA}$ & Willcocks & 1994 \\
\hline \multirow{2}{*}{$\begin{array}{l}\text { Information Polity(Information } \\
\text { Infrastructure and Policy) }\end{array}$} & \multirow[t]{2}{*}{$1996-2007$} & \multirow[t]{2}{*}{ PA } & Pawlowska & 2004 \\
\hline & & & Peled & 2000 \\
\hline Journal of Public Procurement & $2001-2007$ & $\mathrm{PA}$ & No references found & \\
\hline $\begin{array}{l}\text { Journal of Public Administration } \\
\text { Research and Theory }\end{array}$ & $1991-2004$ & PA & No references found & \\
\hline $\begin{array}{l}\text { Government Information } \\
\text { Quarterly }\end{array}$ & $1996-2007$ & PA & No references found & \\
\hline $\begin{array}{l}\text { International Journal of Public } \\
\text { Sector Management }\end{array}$ & $1989-2007$ & PA & No references found & \\
\hline British Journal of Management & & Mgmt & Willcocks and Currie & 1997 \\
\hline Decision Support Systems Journal & & Mgmt & Rapcsak and Zagi & 2000 \\
\hline Revista Venezolana de Gerencia & & Mgmt & Andrade and Mandrillo & 2004 \\
\hline
\end{tabular}


Table 2. Reference from Scientific Information Systems Congresses

\begin{tabular}{|l|c|c|c|}
\hline \multicolumn{1}{|c|}{ Source } & Period & Author & Year \\
\hline International Conference on Information & $2001-2007$ & Zmud et al. & 2004 \\
\cline { 3 - 4 } Systems & & Seddon et al. & 2002 \\
\hline Hawaii International Conference on & $1999-2007$ & Hancox and Hackney & 1999 \\
\cline { 3 - 4 } Information Systems Science. & & Beyah and Gallivan & 2001 \\
\cline { 3 - 4 } & & Lindskog & 2005 \\
\cline { 3 - 4 } & & Moon et al. & 2007 \\
\hline $\begin{array}{l}\text { Americas Conference on Information } \\
\text { Systems }\end{array}$ & $1995-2007$ & Dertz et al. & 2003 \\
\cline { 3 - 4 } & & Chen & 2002 \\
\cline { 3 - 4 } & & Alexander & 2002 \\
\cline { 3 - 4 } & & Chen and Gant & 2001 \\
\cline { 3 - 4 } $\begin{array}{l}\text { European Conference on Information } \\
\text { Systems }\end{array}$ & $1993-2007$ & Lawry et al. & 2007 \\
\cline { 3 - 4 } & & Lewis & 1998 \\
\cline { 3 - 4 } & & Davies & 1993 \\
\cline { 3 - 4 } & & Willcocks and Kern & 1997 \\
\hline $\begin{array}{l}\text { European and Mediterranean Conference } \\
\text { on Information Systems }\end{array}$ & $2004-2007$ & No references found & \\
\hline $\begin{array}{l}\text { Pacific-Asian Conference on Information } \\
\text { Systems }\end{array}$ & $1993-2005$ & No references found & \\
\hline IFIP World Conference on IT Tools & & De Looff & 1996 \\
\hline
\end{tabular}

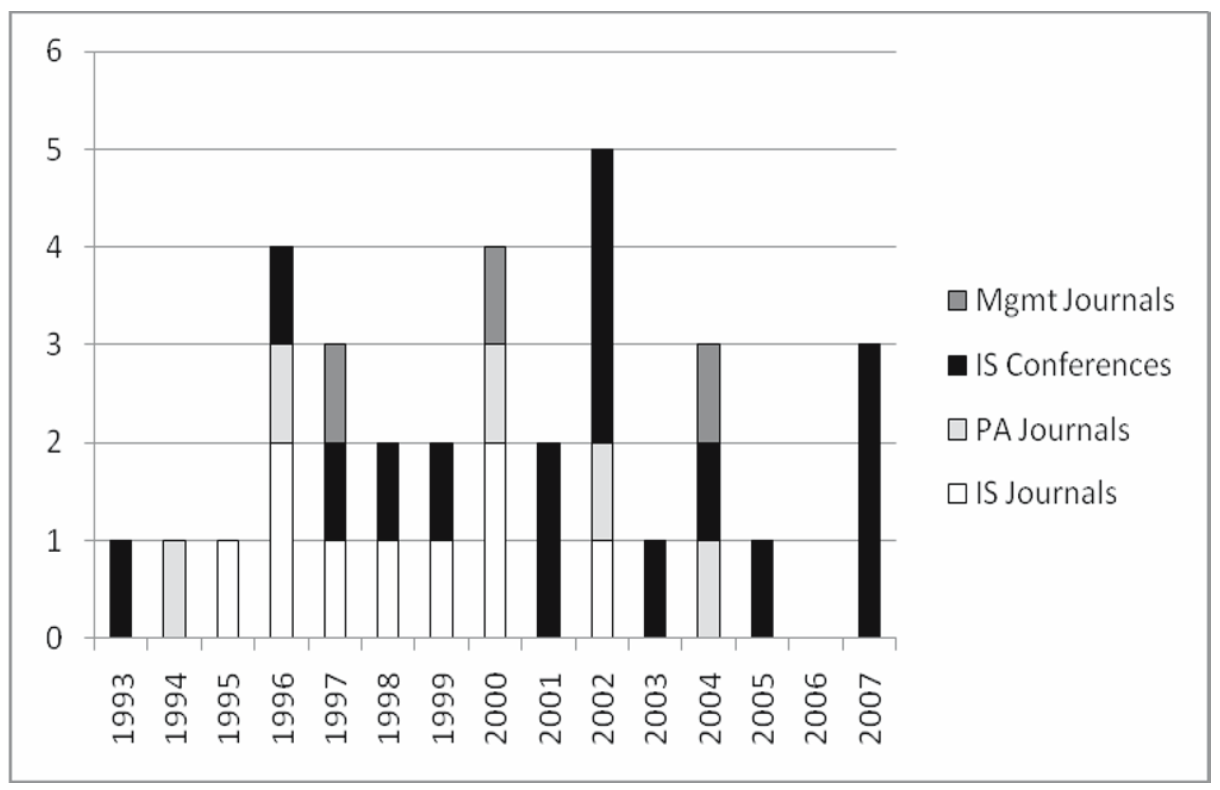

Figure 1. Amount of References, by Year, Field, and Source Type 


\subsubsection{Typology of Case Studies and Related Research}

As usual in the research of other issues in IS, we found significant use of case studies in the contributions reviewed. Table 3 presents both the use type of these case studies and the underlying research method used for their analysis. The table also shows the geographical area of each case, as well as the administrative level of the public administration considered in the case (national/central government; state/regional government; local/municipal government).

Evident from this review is that most of the cases come from English-speaking countries, with a total of eight cases, with only three cases from other places (continental Europe, Israel, and Korea). With regard to administrative level, there are eight cases at central PA level, two at the regional level, and six at the local level. However, it should be noted that in some countries the scope and administrative responsibilities of municipalities are very extensive and can be comparable to those of regional governments in other areas or countries. Thus, in a global sense, our classification of cases in administrative levels is a rough one, more generally descriptive than clear and precise.

If we consider the research purpose of the case studies, three have a mere descriptive intention with some derived recommendations, four are used to validate a hypothesis or framework previously defined, and six bear a more complex purpose. In particular, these latter cases are used either to derive proposals for critical success or risk factors, or to derive conceptual frameworks, and the cases serve to illustrate the proposed factors or frameworks.

The research approaches used are mainly qualitative, including the in-depth case study research method, but up to four cases have been studied with quantitative methods at some points. Table 3 details research techniques for these cases.

\subsubsection{Differences Between PAOs and Private Companies}

One of the recurreing issues in these cases is the differences between the public and the private sectors with regard to IS/IT procurement, and if these differences are significant enough as to justify the development of different theories. It is clear that, according to this review, this is still an open issue.

This topic was directly addressed by Zmud et al. (2004) in a panel at the International Conference on Information Systems. Along a different line, we have found in Davies (1993) the first reference relevant in the topic, with the assumption of a clear difference between PAOs and private companies. Hancox and Hackney (1999, 2000) present a comparison between PAOs and the private sector from the point of view of four different conceptual frameworks. In a similar way, Moon et al. (2007) compare some conclusions about success factors with general beliefs of IT sourcing in the private sector.

The main argument for questioning the differentiation of procurement between PAOs and the private sector is the fact that many aspects that look particular to PAOs also appear in private institutions with similarities to PAOs (for instance, bureaucratic private companies or large companies). These aspects have been addressed by some of the research examined.

- A common shortage of IS management skills, specifically in procurement decisions (offer, supplier study, selection) (De Looff 1996; Lacity and Willcocks 1997) 
Table 3. Case Study Typology with Research Approaches

\begin{tabular}{|c|c|c|c|c|c|}
\hline Author & Year & 胥 & « & $\begin{array}{l}\text { Main Research } \\
\text { Purpose }\end{array}$ & Methodological Aspects \\
\hline $\begin{array}{l}\text { Lacity and } \\
\text { Willcocks }\end{array}$ & 1997 & 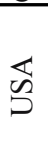 & 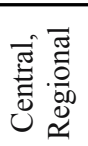 & $\begin{array}{l}\text { Description, comparison } \\
\text { and recommendation }\end{array}$ & $\begin{array}{l}\text { Case-study construction, } \\
\text { qualitative, interpretivist, } \\
\text { short temporal span }\end{array}$ \\
\hline Chen & 2002 & $\underset{\mathscr{D}}{\mathbb{b}}$ & $\begin{array}{l}\overline{\widetilde{J}} \\
0 \\
\end{array}$ & $\begin{array}{l}\text { Hypothesis validation/ } \\
\text { contrast (on success factors) }\end{array}$ & Survey, quantitative \\
\hline Currie & 1996 & 光 & 胥 & $\begin{array}{l}\text { Description, } \\
\text { recommendation }\end{array}$ & $\begin{array}{l}\text { In-depth case analysis, } \\
\text { qualitative, interviews } \\
\text { and questionaires }\end{array}$ \\
\hline $\begin{array}{l}\text { Willcocks } \\
\text { and Currie }\end{array}$ & 1997 & 光 & $\underset{\overparen{E}}{\stackrel{\pi}{0}}$ & $\begin{array}{l}\text { Hypothesis validation/ } \\
\text { contrast (on success } \\
\text { factors), description, } \\
\text { recommendation }\end{array}$ & $\begin{array}{l}\text { In-depth case analysis } \\
\text { and construction, quali- } \\
\text { tative, interviews, inter- } \\
\text { pretivist, long temporal } \\
\text { span }\end{array}$ \\
\hline $\begin{array}{l}\text { Willcocks } \\
\text { and Kern }\end{array}$ & $\begin{array}{l}1997, \\
1998\end{array}$ & 光 & 吾 & $\begin{array}{l}\text { Hypothesis validation/ } \\
\text { contrast (on critical } \\
\text { dimensions), description, } \\
\text { recommendation }\end{array}$ & $\begin{array}{l}\text { In-depth case analysis, } \\
\text { qualitative, interviews, } \\
\text { interpretivist, long } \\
\text { temporal span }\end{array}$ \\
\hline \begin{tabular}{|l|} 
Hancox and \\
Hackney
\end{tabular} & $\begin{array}{l}1999 \\
2000\end{array}$ & 光 & 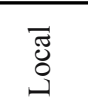 & $\begin{array}{l}\text { Application of conceptual } \\
\text { frameworks, comparison, } \\
\text { conclusions }\end{array}$ & Qualitative, interviews \\
\hline Lewis & 1999 & $\begin{array}{l}\frac{\pi}{\pi} \\
\frac{\pi}{\pi} \\
\frac{\pi}{2} \\
\frac{\pi}{4}\end{array}$ & 苞 & $\begin{array}{l}\text { Proposal of method for } \\
\text { evaluating tenders, descrip- } \\
\text { tive contrast of the method }\end{array}$ & $\begin{array}{l}\text { Personal application and } \\
\text { experience with the } \\
\text { method in two cases }\end{array}$ \\
\hline $\begin{array}{l}\text { Domberger } \\
\text { et al. }\end{array}$ & 2000 & $\frac{\stackrel{\pi}{\pi}}{\stackrel{\pi}{\pi}}$ & 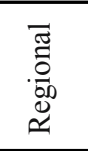 & $\begin{array}{l}\text { Proposal of method for } \\
\text { validation/contrast of other } \\
\text { authors' prior generali- } \\
\text { zations }\end{array}$ & Qualitative, interviews \\
\hline De Looff & 1995 & 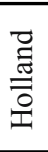 & శ్ర్ర & $\begin{array}{l}\text { Proposal of framework, with } \\
\text { its contrast in the case study }\end{array}$ & $\begin{array}{l}\text { In-depth case analysis, } \\
\text { qualitative, interviews, } \\
\text { interpretivist, long } \\
\text { temporal span }\end{array}$ \\
\hline Dertz et al. & 2003 & 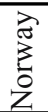 & శ్ర్ల & $\begin{array}{l}\text { Description of decision } \\
\text { criteria for acquisition }\end{array}$ & Surveys \\
\hline Peled & 2000 & 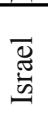 & 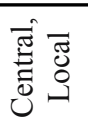 & $\begin{array}{l}\text { Proposal of models, descrip- } \\
\text { tion of cases, proposed } \\
\text { models exemplification }\end{array}$ & $\begin{array}{l}\text { Analysis of described } \\
\text { cases }\end{array}$ \\
\hline Pawlowska & 2004 & $\begin{array}{l}\bar{\Xi} \\
\frac{\pi}{0} \\
0\end{array}$ & 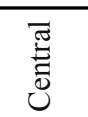 & $\begin{array}{l}\text { Description of large-scale } \\
\text { project cases, failure causes } \\
\text { analysis }\end{array}$ & Analysis of public reports \\
\hline Moon et al & 2007 & 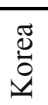 & 要 & $\begin{array}{l}\text { Proposal of success factors } \\
\text { framework }\end{array}$ & $\begin{array}{l}\text { Analysis of documenta- } \\
\text { tion, surveys, quantitative }\end{array}$ \\
\hline
\end{tabular}


- Volatility and dependence of political tendencies and context (Beyah and Gallivan 2001; Looff 1996; Lacity and Willcocks 1997; Willcocks and Kern 1997, 1998)

- Long duration of development projects (mainly of bespoke software development and packaged software implementation), which implies that projects usually survive their leaders (Beyah and Gallivan 2001)

- Difficulties in the retention of specialists (PAOs usually pay less than the private sector) (Currie 1996; De Looff 1996; Lacity and Willcocks 1997)

- Lack of cooperation between departments within the same PAO with similar IS/IT procurement needs, as is often the case within private companies (De Looff, (1996)

- The fact that geographic location usually reduces the amount of providers with relevant skills for the service to be procured, which often implies that local developments become the only alternative (Dertz et al. 2003)

- $\quad$ Specificity and complexity of needs/solutions relevant to both situations (De Looff 1996)

On the other hand, there are aspects that are accepted as clearly exclusive in the PAO domain.

- Public control of the tasks undertaken, of their management and their results (Beyah and Gallivan 2001; Lacity and Willcocks 1997)

- Wherever happens, the mandatory nature of some outsourcing plans of some PAOs, such as the case of Compulsory Competitive Tendering in Great Britain (Currie 1996) and the National Performance Review in the United States (Hancox and Hackney 1999, 2000)

\subsubsection{Services to Outsource/Procure and Reasons for Doing So}

Whenever an organization confronts the possibility of undertaking the outsourcing of some of its IS/IT services, the first questions that arise are those related to the scope of such an externalization. That is, whether a wide service area should be externalized (total outsourcing) or if only some chosen functions or services should (selective sourcing), and in this case, which ones are the best candidates.

While total outsourcing was the first default option, because of pressures for reducing costs in PAOs, it can also have many drawbacks. Foremost, total outsourcing can make the organization highly dependent on providers, with the implied risks. The de facto monopolistic nature of this option may derive in losing control of IS/IT strategic decisions (Willcocks and Currie 1997).

In the light of the studied cases and some of the reported experiences with total outsourcing, most of them far from successful, selective sourcing appears as a more reasonable option (Beyah and Gallivan 2001). In fact, Willcocks and Kern (1997, 1998) present in their conclusions their clear belief that PAOs in the United Kingdom in the mid-1990s were only ready to successfully manage short-span contracts in the context of selective sourcing.

Regarding those IS/IT services or functions that can be outsourced, there is a clear consensus about the starting point, which are commodities, that is, those IS/IT functions that are not considered as core to the business or PA service mission (Davies 1993; Dertz 
et al. 2003; Willcocks 1994; Willcocks and Currie 1997). These functions, which include the procurement and operation of IT infrastructures (such as hardware, networks, and basic software) are easier to outsource because they are more tangible, they can be delimited, and they usually have wider and less specialized offerings. Under these circumstances, it becomes viable to accomplish the main advantages of outsourcing: costs advantages, access to expertise, quality of service, adaptability to changes, and core business concentration. Plus, with this option, relationships can usually be restricted to relatively short contracts, from 1 to 5 years, a period that is usual in other types of procurement contracts. More complex or longer projects, given their volume or when they imply very specific software development, are clearly inconvenient: only a few providers, usually very large, can address them (Globerman and Vining 1996; Pawlowska 2007). In these cases, we have as key factors the management of their inherent risk, the formulation of a correct contract, and the adequate management of such a contract over that long period.

Irrespective of what is outsourced, up to what level, and of the underlying motivations, from the structure of PAOs, there are basically two different situations that will condition the outsourcing politics and their adaptation:

- Given that PAOs usually have problems in hiring and keeping the best professionals (for several reasons such as public hiring constraints and salary limitations), outsourcing becomes a good alternative to obtain these competencies from a service provider (Chen 2002; De Looff 1996; Slaughter and Ang 1996). In other words, often PAOs may not spend their budgets on new personnel but can spend similar or greater amounts for contracting externally the service.

- Outsourcing becomes an alternative to overcome PAO inflexibilities and to promote change in the bureaucratic procedures, in order to introduce new management processes or tendencies, such as those under the label of e-government (Chen 2002).

\subsubsection{Practices, Methods, and Methodologies}

On a conceptual level, the following actions are among those considered successful behaviors, practices, and customer attitudes when facing outsourcing projects:

- To avoid running too fast toward outsourcing agreements, for example, by believing uncritically in market trends promoted by private providers when PAO investment decays or in easy cost or performance improvements, all in all ignoring experiences of failure in the private sector (Willcocks 1994; Willcocks and Currie 1997).

- The deep involvement of IS/IT executives, since their responsibility cannot also be externalized by outsourcing strategic analyses and decisions to the provider or to the technical staff (Chen 2002; Davies 1993).

- The need to adapt the CIO role to the particular characteristics of the PAO (Lawry et al. 2007), in order to align it to the specific PAO demands. This adaptation includes increasing the number of responsibilities related to the management of solutions, projects, risks, and portfolios; the promotion of standardization processes; the depicting of outsourcing agreements; or the assessment of the delivered services to the final users. 
- The need to establish within the organization of a strong team with adequate management responsibilities and skills with regard to typical outsourcing processes: offer preparation, analysis of providers, provider selection, contract negotiation and preparation, project monitoring, etc. (Davies 1993; Pawlowska 2004; Willcocks 1994; Willcocks and Currie 1997).

- The need to establish and maintain within the organization a technically strong team that could eventually opt for in-sourcing some projects; in other words, that could present an internal offer in competition with the external providers and win it (Willcocks and Currie 1997).

In short, this means becoming what Willcocks and Currie (1997) call a successful contractual organization - changing IS/IT management within the PAO in order to end up with a less rigid organization, with less tendency to conflict and with more adaptability.

In a more detailed manner, but also along the same line, Hancox and Hackney (1999, 2000) present four conceptual frameworks (not just for PAOs) that may help to study the nature and form of outsourcing projects, to make decisions, and to manage the process.

- Core competences: In order to choose the functions and services to be outsourced, basically those that are not central to the activity of the organization and that may not report competitive advantages (Davies 1993; Dertz et al. 2003; Willcocks 1994; Willcocks and Currie 1997). Since certain uses or developments of IS and IT can eventually provide competitive advantages for some organizations, outsourcing decisions have to be taken with care and consideration to these issues.

- Transaction costs economics: In order to decide which is the best offer, not just thinking about production costs, but also about those costs for establishing and maintaining the outsourcing relationship. Among the factors that increase these coordinating costs are the specificity level of the product or service outsourced as well as the uncertainty in its development (Globerman and Vining 1996).

- Agency theory: In order to ensure maximum control in the outsourcing relationship, the contract details regarding expected behaviors and results become key to success, taking into account that the outsourcing customer and provider usually have business goals that do not always converge, with each party looking after their own interests.

- Partnership: In order to facilitate the maximum possible understanding and coresponsibility in their relationship, such a partnership must be seen as a strategic alliance by fostering the convergence and sharing of project goals among customer and provider. In other words, rather than just signing a contract (fast and too optimistically), it is much better for each party to take their time in writing the correct one, so that their relationship becomes more authentic and strategic, working toward a network organization work structure with a win-win philosophy (Davies 1993; Willcocks 1994; Willcocks and Kern 1997, 1998).

Along this same outsourcing materialization level, Lewis (1999) proposes a method based on the preventive and anticipative evaluation of those risks associated with the offer (such as uncertainty and inadequate use of requirements, technical limitations of providers, overcosts and overruns in the tender process, among others), thus also anticipating the appropriate redresses if any of those risks arise. Also with regard to risks, 
Pawlowska (2007) presents a study of failed cases from the point of view of decisionmaking theory and of organizational theory.

Finally, in a more procedural and evaluative level, we find the proposal of Domberger et al. (2000), who present a quantitative method in the context of commodity outsourcing, with the aim of determining factors and relevancy measures around price and contract performance.

\section{OPEN LIST OF FUTURE CHALLENGES}

We believe that there is still plenty of room for more detailed research in outsourcing IS/IT services by PAOs, not just because of the relatively small volume of published research but also because there a need for more results in this particular growing trend. From the review of prior literature, and from our own experience, we present below an open list of possible research topics, classified by the same categories used in the previous section. We want to remark here that this is a tentative list, a starting point that should be validated in future work. We also make this attempt given that we have not found any similar proposal of general future challenges in our review work. We rely more directly on the third author of this paper, Rafael Macau, who held during many years the position of CEO for an IS/IT public company established by the Catalan autonomous government, and who was in charge of organizing and putting into practice a total outsourcing project for the unit. He has also held several executive posts in global IS/IT services companies. Thus, he has plenty of experience with both sides of IS/IT procurement.

\subsection{Typology of Case Studies and Related Research}

- Many more cases of PAO procurement of IS/IT services should be reported and studied in detail. Those cases should be compiled in wide case base.

- Both current and future cases should be analyzed and grouped by the related PA domains and, by comparing and cross-analyzing them, a first list of common and particular trends should be derived.

- Further analysis and in-depth comparison of the few existing conceptual frameworks should be pursued, eventually generating a general and more inclusive framework for future qualitative validation with reported cases.

- The few research frameworks should be extended and adapted for validating quantitatively those points in PAO IS/IT procurement that prove amenable to this type of validation.

\subsection{Differences Between PA and Private Companies}

- An issue that requires additional research attention is the relevancy and applicability to PAOs of those assumptions and procedures that seem to work for IS/IT procurement in private companies. 
- In the reverse direction, study when some assumptions and procedures usually considered in PAOs could also be useful for private situations, as indicated by the growth of eProcurement projects also in private companies.

- To continue questioning and validating the importance of those aspects that some authors consider as differing in PAOs from private companies, so that in the future this can justify the need or not of separate theories for the two situations.

\subsection{Services to Outsource/Procure and Reasons for Doing So}

- To describe and report on the criteria used for deciding and managing (total or selective) outsourcing agreements, and to study the differences according to PAO levels.

- To study if there exist differences in the procurement decision depending on the final user of the procured service: civil servants (internal use) or citizens (external use, such as that of eGovernment systems).

- To define and study the perception and expectations of the outsourcing parts, and stakeholders in general, and to validate whether they are confirmed or not, and more specifically with regard to better access to professional competencies as well as avoidance of organizational inflexibilities.

\subsection{Practices, Methods, and Methodologies}

- To report and analyze the usage level and impact of the use by PAOs for IS/IT procurement of relevant standards and methods that have appeared in the past, such as Euromethod, ISPL, CMMI, COBIT, and ITIL. Note that we have not found any contribution to this subject in our state-of-the-art review, even though some of the methods do have a public origin (such as Euromethod, CMMI, and ITIL).

- To report and study if the general trend to so-called network organizations, virtual organizations, or contractual organizations poses specific dependency risks in outsourcing agreements in the case of IS/IT services.

- To understand what roles are put into place in IS/IT services procurement agreements, from both parties, and their usual expectations and responsibilities, as well as their evaluations.

- To do a more in-depth description and validation of critical success and risk factors in the outsourcing of complex IS/IT functions and services.

- To continue analyzing and validating the metrics for explaining successful or satisfactory situations in PAO procurement of IS/IT services.

- To study how procedures and mechanisms that are used and accepted for other types of PAO procurements may influence, be adapted, or combined for procuring IS/IT services.

- To report on, propose, and apply relationship management frameworks for improving the overall success or satisfaction levels of the outsourcing relationship, such as ad hoc balanced scorecards. 


\section{THE CASE OF GENERALITAT DE CATALUNYA}

We believe it would be interesting to increase the number of explained cases. In order to make our little contribution in this sense, here we outline one of the main cases that we have started to study, that of the Generalitat de Catalunya, the public administration of Catalonia's autonomous government, within Spain. Our study is now in an initial phase, so in this section we only want to describe the case and to mention the aspects we want to study.

In Spain, autonomous governments (called autonomías) are decentralized administrations that manage the 19 different regional territories that make up the Spanish state, each one of them with different degrees of influence and attributions in economic and political terms. Catalonia is the second most populated region and the one currently making the greatest contribution to Spain's production of goods and services (GDP: 20.8 percent in 2005).

The history of IS/IT deployment and management at the Generalitat has followed a typical pattern (Aibar et al. 2006). At the beginning of the 1980s, each department had its own IS group, a situation that produced unavoidable inefficiencies. In 1983, a central office in the form of a publicly owned company, CIGESA, was created, by concentrating both human and technological resources and becoming the IS/IT provider for all of the different departments of the Generalitat. CIGESA achieved high levels of efficiency but it also grew very fast, matching the growing needs of Generalitat. In order to avoid an unaffordable company size (in terms of technical teams and their skills), two possibilities were considered: selective and total outsourcing. At this point, Rafael Macau was CIGESA's CEO.

Total outsourcing was then the chosen option, pushed by the management and political trends of the moment, in spite of some of Generalitat's managers who considered selective outsourcing as a more appropriate decision. So, in 1998, CIGESA was finally sold to a German group, Debis, that some years later was taken over by Deutsche Telekom (Gelonch 1999). The sale included two contracts: one directly related to the CIGESA acquisition and the other related to a four-year servicing relationship. In terms of the first contract, the company had to keep the human resources inherited from CIGESA. In terms of the second one, the company also had to keep a simplified administrative process to respond to the provision for the Generalitat public projects. These temporary simplifications and guarantees did not produce a monopolistic situation given that, in the subsequent years, almost 50 percent of the acquisitions were made to other companies. In addition, as a way of controlling the relationships with all of the different providers, including Debis, CTTI was created. CTTI (IT and Telecommunications Center) is an internal entity within the Generalitat that also is responsible for the policy making and management of IT. Rafael Macau became the director of CTTI for IS/IT projects.

However, during the following years some criticism about this supposedmonopolistic relationship reemerged as well as some doubts about lack of price competitiveness and risky dependencies on the provider of the services. A change in the political government of Generalitat in 2003, prompted a reorientation toward a more explicit selective sourcing strategy. Hence, in 2004, procurement activities were addressed to create a pool of authorized providers by prequalifying them. So, after the 
companies passed a certification process, they were allowed to make a bid to the different Generalitat project proposals.

The current stage of this story is that we believe that this case needs to be studied in depth as it can be of research interest, four years after of its commencement, to understand how it has impacted IS/IT services both at the user and at the provider level, among other issues. Similar experiences of prequalification are found in the private sector but not in the public one. So, from an in-depth study of this case, we hope to shed light on the real application of selective sourcing and the prequalifying process in a large and complex situation of PAO procurement of all of its IS/IT services, the impact this has on the customer-provider relationship, and the results achieved, measured in terms of success and satisfaction indicators.

\section{CONCLUSIONS}

We have presented in this paper the current research status of public administration procurement of IS/IT functions and services. We believe that this is a wide-open issue that has not yet received enough attention from the research community, given the great amount of public money that is being invested without enough validated information.

In addition to the research survey, right now more useful for researchers than for practitioners, we have presented a list of open research and practical issues that we are starting to consider in an in-depth case study that we have recently undertaken. We intend to share our study with those interested in this topic, and we invite the IS and PA research communities to put this topic in an appropriate position within the research agenda.

\section{References}

Aibar, E., Urgell, F., and Web, Y. 2006. "L'organització i la gestió de la informàtica," Chapter 9 in Project Internet Catalonia (PIC): E-governance and Citizens in the Generalitat of Catalonia, (Catalan version) (http://www.uoc.edu/in3/pic/cat/pdf/PIC_Generalitat_2_9.pdf).

Alexander, C. 2002. "Outsourcing Information Systems: An Alternative for Local Government," in Proceedings of the $8^{\text {th }}$ Americas Conference on Information Systems, R. Ramsower and J. Windsor (eds.), Dallas, TX, pp. 2128-2133.

Allen, D., Kern, T., and Mattison, D. 2002. "Culture, Power and Politics in ICT Outsourcing in Higher Education Institutions," European Journal of Information Systems (11:2), pp. 159-173.

Andrade, J. A., and Mandrillo, C. 2004. "El outsourcing de los sistemas de información en las organizaciones públicas," Revista venezolana de gerencia (9:28), pp. 607-622.

Beyah, G., and Gallivan, M. 2001. "Knowledge Management as a Framework for Understanding Public Sector Outsourcing," in Proceedings of the $34^{\text {th }}$ Hawaii International Conference on System Sciences, Los Alamitos, CA: IEEE Computer Society Press.

Chen, Y. C. 2002. "Managing E-Government Outsourcing Projects: Lessons from U.S. Local Government," in Proceedings of the $8^{\text {th }}$ Americas Conference on Information Systems, R. Ramsower and J. Windsor (eds.), Dallas, TX, pp. 558-563.

Chen, Y. C., and Gant, J. 2001. "Transforming E-Government Services: The Use of Application Service Providers in U.S. Local Governments," in Proceedings of the $7^{\text {th }}$ Americas Conference on Information Systems, D. Strong and D. W. Straub (eds.), Boston, pp. 1605-1610. 
Currie, W. L. 1996. "Outsourcing in the Private and Public Sectors: An Unpredictable IT Strategy, " European Journal of Information Systems (4:4), pp. 226-236.

Danziger, J. N., and Andersen, K. V. 2002. "The Impacts of Information Technology on Public Administration: An Analysis of Empirical Research from the 'Golden Age' of Transformation," International Journal of Public Administration (25:5), pp. 591-627.

Davies, A. 1993. "The Implications of Outsourcing for Information Management in the Public Sector,"in Proceedings of the First European Conference on Information Systems, E. A. Whitley (ed.), Henley-on-Thames, United Kingdom, pp. 1-8.

Dekker, J., and Hendriks, L. 2002. "Best Practice in Acquisition and Procurement Management: the Information Services Procurement Library" in The Guide to IT Services Management, J. van Bon (ed.), London: Addison-Wesley, pp. 277-296.

De Looff, L. A. 1995. "Information Systems Outsourcing Decision Making: A Framework, Organizational Theories and Case Studies," Journal of Information Technology (10), pp. 281297.

De Looff, L. A. 1996. "IS Outsourcing by Public Sector Organizations," in Advanced IT Tools (Proceedings of the IFIP World Conference on IT Tools, $14^{\text {th }}$ WCC, N. Terashima and E. Altman (eds.), London: Chapman \& Hall, pp. 89-96.

Dertz, W., Moe, C., and Hu, Q. 2003. "Influential Factors in IT Sourcing Decisions of Norwegian Public Sector: An Exploratory Study," in Proceedings of the $9^{\text {th }}$ Americas Conference on Information Systems, J. Ross and D. Galletta (eds.), Tampa, FL, pp. 1614-1622.

Dibbern, J., Goles, T., Hirschheim, R., and Jayatilaka, B. 2004. "Information Systems Outsourcing: A Survey and Analysis of the Literature," SIGMIS Database (35:4), pp. 6-102.

Domberger, S., Fernandez, P., and Fiebig, D. G. 2000. "Modeling the Price, Performance and Contract Characteristics of IT Outsourcing, ” Journal of Information Technology (15:2), pp. 107-118.

González, R., Gascó, J., and Llopis, J. 2006. "Information Systems Outsourcing: A Literature Analysis," Information and Management (43:7), pp. 821-834.

Gelonch, A. 1999. Incrementant l'eficàcia de l'administració i el sevei als cituadans: El procés d'externalització dels serveis informàtics de la Generalitat de Catalunya. Barcelona: Universitat Ramon Llull.

Globerman, S., and Vining, R. 1996. "A Framework for Evaluating the Government ContractingOut Decision with an Application to Information Technology," Public Administration Review (56:6), pp. 577-586.

Guah, M. W., and Currie, W. 2007. "Managing Vendor Contracts in Public Sector I.T.: A Case Study on the UK National Health Service," in Proceedings of the $15^{\text {th }}$ European Conference on Information Systems, H. Österle, J. Schelp, and R. Winter (eds.), St. Gallen, Switzerland, pp. 2147-2160.

Hancox, M., and Hackney, R. 1999. "Information Technology Outsourcing: Conceptualizing Practice in the Public and Private Sector," in Proceedings of the $32^{\text {nd }}$ Hawaii International Conference on System Sciences, Los Alamitos: IEEE Computer Society Press.

Hancox, M., and Hackney, R. 2000. "IT Outsourcing: Frameworks for Conceptualizing Practice and Perception," Information Systems Journal (10:3), pp. 217-237.

Helmerich, A. 1998. "Euromethod Contract Management," in Handbook on Architectures of Information Systems, P. Bernus, K. Mertins, and G. Schmidt (eds.), Boston: Springer, pp. 521-534.

Hoffman, H. F., Yedlin, D. K., Mishler, J. W., and Kushner, S. 2007. CMMI for Outsourcing: Guidelines for Software, Systems and IT Acquisition, Boston: Addison-Wesley.

Lacity, M., and Willcocks, L. P. 1997. "Information Systems Oourcing: Examining the Privatization Option in USA Public Administration, "Information Systems Journal (7:2), pp. 85-108.

Lawry, R., Waddell, D., and Singh, M. 2007. "CIO's in the Public Sector: The Gap Between Theory and Reality," Proceedings of the $12^{\text {th }}$ Americas Conference on Information Systems, L. Chidambaram and S. Ram (eds.), Keystone, CO, August 10-12. 
Lee, J. N., Huynh, M. Q., Kwok, R. C. W., and Pi, S. M. 2003. "IT Outsourcing Evolution-Past, Present, and Future," Communications of the ACM (46:5), pp. 84-89.

Lewis, E. J. E. 1998. "The Use of the Risk-Remedy Method for Evaluating Tenders for Outsourcing Information Technology in the Australian Public Sector," in Proceedings of the $6^{\text {th }}$ European Conference on Information Systems, W. Baets, Aix-en-Provence, France, pp. 598-611.

Lewis, E. J. E. 1999. "Using the Risk-Remedy Method to Evaluate Outsourcing Tenders," Journal of Information Technology (14;2), pp. 203-211.

Lindskog, H. 2005. "SOTIP as a Model for Outsourcing of Telecom Services for the Public Sector," in Proceedings of the $38^{\text {th }}$ Hawaii International Conference on System Sciences, Los Alamitos, CA: IEEE Computer Society Press.

Marco-Simó, J. M., Macau-Nadal, R., and Pastor-Collado, J. A. 2007. "Information Systems Outsourcing in Public Administration: An Emergent Research Topic," in Proceedings of the $4^{\text {th }}$ European and Mediterranean Conference on Information Systems, M. Rodenes and R. Hackney, Valencia, Spain, pp. 51,01-51,10.

Moon, J., Jung, G., Chung, M., and Chang, Y. 2007. "IT Outsourcing for E-Government: Lessons form IT Outsourcing Projects Initiated by Agricultural Organizations of the Korean Government," in Proceedings of the $40^{\text {th }}$ Hawaii International Conference on System Sciences, Los Alamitos, CA: IEEE Computer Society Press.

Peled, A. 2000. "The Politics of Outsourcing: Bureaucrats, Vendors, and Public Information Technology (IT) Projects," Information Infrastructure and Policy (6), pp. 209-225

Pawlowska, A. 2004. "Failures in Large Systems Projects in Poland: Mission [Im]Possible?," Information Polity (9), pp. 167-180

Rapcsak, T., and Zagi, Z. 2000. "Evaluation of Tenders in Information Technology," Decision Support Systems (30:1), pp. 1-10.

Seddon, P. B., Cullen, S., and Willcocks, L. P. 2002. "Does Domberger's Theory of the Contracting Organization Explain Satisfaction with IT Outsourcing?," Proceedings of the $23^{\text {rd }}$ International Conference on Information Systems, L. Applegate, R. D. Galliers, and J. I. DeGross (eds.), Barcelona, pp. 593-604.

Slaughter, S., and Ang, S. 1996. "Employment Outsourcing in Information Systems," Communications of the ACM (39:7), pp. 47-54.

Sood, R. 2007. "Report Highlight for Dataquest Insight: Partnering in the Federal Government Market," Gartner Reports, ID Number: G00145921.

Willcocks, L. P. 1994. "Managing Information Systems in UK Public Administration: Issues and Prospects," Public Administration (72), pp. 13-32.

Willcocks, L. P., and Currie, W. L. 1997. "Information Technology in Public Services: Towards the Contractual Organization?," British Journal of Management (8:1), pp. 107-120.

Willcocks, L. P., and Kern, T. 1997. "IT Outsourcing as Strategic Partnering: The Case of the UK Inland Revenue," in Proceedings of the $5^{\text {th }}$ European Conference on Information Systems, R. Galliers (ed.), Cork, Ireland.

Willcocks, L. P., and Kern, T. 1998. "IT Outsourcing as Strategic Partnering: The Case of the UK Inland Revenue,” European Journal of Information Systems (7:1), pp. 29-45.

Zmud, R., Carte, T., and Te'eni, D. 2004. "Information Systems in Nonprofits and Governments: Do We Need Different Theories?," in Proceedings of the $25^{\text {th }}$ International Conference on Information Systems R. Agarwal, L. Kirsch, and J. I. DeGross (eds.), Washington, DC, pp. 1017-1018.

\section{About the Authors}

Josep Maria Marco-Simó holds an M.Sc. in Informatics. He is an assistant professor at Universitat Oberta de Catalunya (since 2001) and program director of Technical Engineering in 
Computer Management (since 2003) at the same university. His teaching topics are related to management of information systems and software development. His research interests include information systems, ICT in the public sector, virtual organizations, and collaborative learning. Josep can be reached at jmarco@uoc.edu.

Joan Antoni Pastor holds an M.Sc. in Informatics and a Ph.D. in Software Engineering from Universitat Politècnica de Catalunya and a Global Senior Management Program from the University of Chicago Graduate School of Business and Instituto de Empresa Business School. $\mathrm{He}$ is an assistant professor at Universitat Oberta de Catalunya (since 2007) and a part-time lecturer at Universitat Politècnica de Catalunya. He has held several university management posts, and is starting a new research group on Information Systems and Services at UOC. His teaching and research topics are centered on information systems, IS/IT services management, software engineering, services science and curricula innovation. Joan can be reached at jpastorc@uoc.edu.

Rafael Macau holds three M.Sc. degrees, respectively, in Mathematics, Informatics, and Journalism. He is an assistant professor at Universitat Oberta de Catalunya (since 2001), and currently serves as dean of the Studies of Informatics, Multimedia and Telecommunications at that institution. He has held several executive and management posts in global IS/IT services companies and in public administration IS/IT units. His teaching and research interests are centered in information systems, IS/IT services management, services science, and people management issues in knowledge-intensive services companies. Rafael can be reached at rmacau@uoc.edu. 